\title{
Plasma Membrane Insulin Receptors in Fetal Rabbit Lung
}

\author{
NAOMI D. NEUFELD, ${ }^{(37)}$ LUCILLE M. CORBO, \\ AND SOLOMON A. KAPLAN \\ Section of Pediatric Endocrinology, Department of Pediatrics, Cedars-Sinai Medical Center, and Department of \\ Pediatrics, UCLA Center for Health Sciences, Los Angeles, California, USA
}

\section{Summary}

Previous studies have suggested that fetal hyperinsulinemia which occurs in offspring of diabetic mothers is responsible for diminished surfactant production and respiratory distress syndrome. Recognition of specific insulin effects on fetal lung tissue prompted us to characterize insulin receptors on plasma membranes of fetal rabbit lung tissue and to investigate the effects of maternal diabetes on such receptors. Six pairs of pregnant New Zealand rabbits were studied. One of each pair received alloxan $(60 \mathrm{mg} / \mathrm{kg})$ intravenously on day 14 of pregnancy, whereas the controls received saline. Animals were sacrificed on day 28 of gestation, and for each experiment, crude plasma membranes were prepared from maternal and pooled fetal lung tissue for ${ }^{125} \mathrm{I}$-insulin binding studies. Plasma glucose values were elevated for both maternal diabetic $(246 \pm 81$ versus $98.5 \pm 7.1 \mathrm{mg} / \mathrm{dl} ; P<0.001)$ and fetal diabetic offspring (160 \pm 69 versus $55 \pm 12 \mathrm{mg} / \mathrm{dl} ; P<$ 0.02 ) in comparison to controls. Fetal diabetic offspring had plasma insulin values significantly higher than control fetuses $(84.8$ \pm 25 versus $23.2 \pm 3.7 \mu \mathrm{U} / \mathrm{ml}$ ), (mean \pm S.D.); $P<0.05$ ). Insulin was undetectable in diabetic mothers.

Lung membranes from fetuses of diabetic animals bound significantly more insulin than did those of control fetuses. Scatchard analysis yielded curvilinear plots of bound fractions versus total amount of insulin bound suggesting the presence of more than one class of receptors or negative cooperativity. Assuming two classes of receptors, one of high affinity and low capacity and another of low affinity and high capacity, we found that fetal membranes had a five-fold increase in binding capacity of high-affinity receptors as compared to adult membranes. In spite of marked hyperinsulinemia in the offspring of the diabetic animal, the fetal lung, far from experiencing a down-regulation of insulin receptor binding, showed increased insulin binding. This finding is consistent with observations made previously on circulating monocytes of infants of diabetic mothers.

\section{Speculation}

Hyperinsulinemia occurring postnatally appears to lead to down-regulation of insulin binding. Although the mechanisms of down-regulation are not clearly understood, from a teleological standpoint the phenomenon may be viewed as partially protecting the organism from the effects of hyperinsulinism because less binding sites are available for insulin to exert its effects on target tissues. In the fetus, this protective mechanism does not appear to exist in at least two tissues examined thus far, circulating monocytes of the human and lung tissue of the rabbit. The fetus with hyperinsulinemia may therefore be subject to the double jeopardy of higher concentrations of insulin and higher binding of insulin to its target tissues.

Neonatal respiratory distress syndrome (RDS) has been recognized as a major factor in the morbidity and high mortality rates of infants of diabetic mothers) for 20 years, however, the cause is not well defined (9). Certain factors such as degree of prematurity and the route of delivery contribute to the greater than normal incidence of RDS in these infants. When such factors are controlled for in the analyses of available data, however, the incidence of RDS remains 5- to 6-fold greater than IDM than in the normal population (27) unless maternal diabetes is rigidly controlled during inpatient supervision of the mother in the latter part of her pregnancy (14).

Insufficient quantities of surface-active phospholipids in the neonatal lung are associated with development of RDS (4). Studies by others and ourselves have shown that insulin in concentrations comparable to those observed in IDM at birth can significantly impair the synthesis of surface active phospholipids by fetal lung tissue in vitro $(12,21,30)$. Recognition of the specific effects of insulin on this critical aspect of fetal lung metabolism prompted us to characterize properties of insulin receptors in fetal lung tissue. Furthermore, inasmuch as maternal diabetes is known to affect the properties of insulin receptors in other tissues (19), it was necessary to investigate the effects of maternal diabetes on fetal lung receptors.

\section{MATERIALS AND METHODS}

Twelve pregnant New Zealand albino rabbits, conception timed to within $3 \mathrm{hr}$, were studied in pairs in six separate experiments. Six animals received alloxan ( $60 \mathrm{mg} / \mathrm{kg}$ body weight) in sterile $0.9 \% \mathrm{NaCl}$ solution intravenously on day 14 of pregnancy, at a time when this injection is known to cause minimal disturbance of fetal pancreatic endocrine function (2). For $24 \mathrm{hr}$ after the injection, these animals received $10 \%$ dextrose in water for drinking. The remaining animals, which served as controls, received intravenous saline without alloxan. On day 28 of gestation, the fetuses were delivered by caesarean section after sacrificing the doe with intravenous pentobarbital followed by $\mathrm{KCl}$, as described previously (21). Both fetal and adult lungs were excised, placed in ice-cold saline, blotted and extraneous bronchial tissue dissected away.

For each experiment, plasma membranes from pooled fetal lungs and adult lung were prepared by modification of the method described by Morishige et al. (18). Lung tissue was minced with scissors, placed in $0.3 \mathrm{M}$ sucrose, homogenized on ice using a Polytron homogenizer, and filtered through 2 to 3 layers of cotton gauze. The filtered homogenate was centrifuged at $3000 \times \mathrm{g}$ for $10 \mathrm{~min}$. The supernatant fraction was recovered and centrifuged at $16,000 \times g$ for $20 \mathrm{~min}$. The resultant membrane pellet was washed twice in $50 \mathrm{mM}$ Tris buffer (pH 7.6) and resuspended at a final concentration of $1 \mathrm{~g}$ original wet weight to $2 \mathrm{ml}$ Tris buffer. All steps were carried out at 0 to $4^{\circ} \mathrm{C}$. Insulin binding studies were performed immediately after membrane preparation because significant diminution in binding was observed to occur within 2 to 7 days (18). Maternal and pooled fetal blood were saved for subsequent determination of glucose and insulin concentrations. 
Mono-iodo- ${ }^{125} \mathrm{I}$-insulin with a specific activity of 80 to $150 \mu \mathrm{Ci} /$ $\mu \mathrm{g}$ was prepared by the method of Freychet et al. (8). Binding of ${ }^{125}$ I insulin to plasma membranes was determined in duplicate after $3 \mathrm{hr}$ incubation at $4^{\circ} \mathrm{C}$. Resuspended membranes were incubated with $50 \mu \mathrm{l}$ of ${ }^{125} \mathrm{I}$-insulin in $50 \mathrm{mM}$ Tris buffer $(\mathrm{pH} 7.4)$ containing $1 \%$ bovine serum albumin and unlabeled insulin in concentrations ranging from $0.2 \mathrm{ng} / \mathrm{ml}$ to $100 \mu \mathrm{g} / \mathrm{ml}$ in a final volume of $0.5 \mathrm{ml}$. Final membrane protein concentrations ranged from 0.5 to $1.5 \mathrm{mg} / \mathrm{ml}$. Bound insulin was separated from unbound insulin by vacuum suction in a manifold filtration apparatus (Millipore Corporation), with cellulose acetate filters of pore size $0.45 \mu$. Each filter was washed with $10 \mathrm{ml}$ ice-cold buffer, and radioactivity remaining on the filter was determined in a well counter.

Comparison of degradation rates of ${ }^{125} \mathrm{I}$-insulin by lung membrane preparations was made by incubating $100 \mu \mathrm{l}$ of ${ }^{125} \mathrm{I}$-insulin, approximately $0.2 \mathrm{ng}$, as used in the binding assay in $100 \mu \mathrm{l}$ glycine- $\mathrm{NaOH}$ buffer (ph 8.6) and $1 \%$ bovine serum albumin, with $100 \mu \mathrm{l}$ of membrane suspension in duplicate at $37^{\circ} \mathrm{C}$ for up to 30 min. Duplicate $20 \mu \mathrm{l}$ aliquots of this incubation mixture were taken at $0,5,10$, and $30 \mathrm{~min}$, added to $0.5 \mathrm{ml}$ Tris buffer and 0.5 $\mathrm{ml} \mathrm{10 \%} \mathrm{trichloroacetic} \mathrm{acid} \mathrm{on} \mathrm{ice.} \mathrm{The} \mathrm{trichloroacetic} \mathrm{acid} \mathrm{precip-}$ itate was recovered, and percent degradation was calculated from the decrease in precipitable counts corrected for the decrease in counts observed in control tubes incubated without lung tissue.

Specific binding of ${ }^{125} \mathrm{I}$-insulin to lung plasma membranes under equilibrium conditions was calculated from the differences between insulin bound in the presence and absence of unlabeled insulin $(100 \mu \mathrm{g} / \mathrm{ml})$. Nonspecific binding, expressed as the percentage of total radioactive counts added, was $1.4 \% \pm 0.4 \%$ for fetal tissues and $1.9 \pm 0.5$ for maternal tissues. Under the conditions of assay, specific binding of tracer insulin was shown to increase linearly with increasing lung membrane protein concentrations (Fig. 1). All data were normalized to a final membrane protein concentration of $1 \mathrm{mg} / \mathrm{ml}$.

Data from competitive insulin binding studies was subjected to Scatchard analysis (28). Binding capacities and equilibrium constants determined from such analyses using a model of two receptor classes (7) followed the procedure of regression analysis as outlined by Blanchard et al. (5).

Activity of $5^{\prime}$-nucleotidase in homogenates and crude membranes was determined by the method of Aronson and Touster (3). Inorganic phosphate was assayed by a colorimetric procedure described by Ames (1). Protein was determined by the procedure of Lowry et al. (17). All assays were performed within 2 wk of membrane preparation. Plasma glucose was determined by reduction of ferricyanide on an Autoanalyzer. Insulin was measured by radioimmunoassay according to the method of Soeldner and Slone (31).

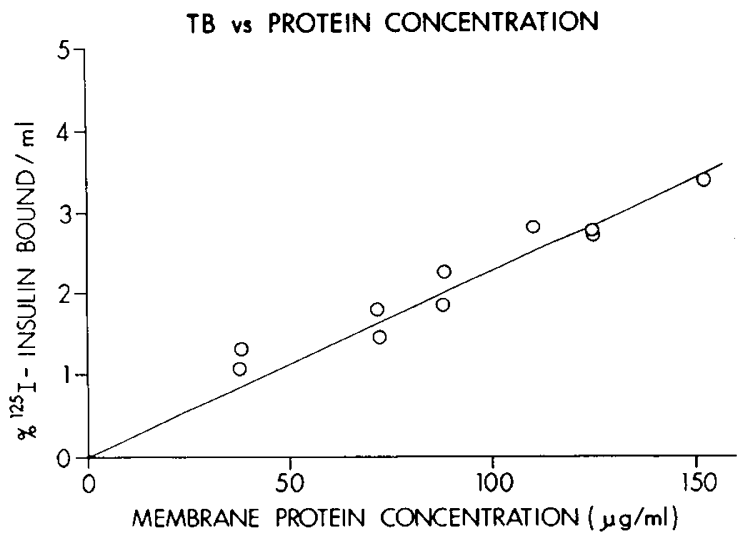

Fig. 1. Percent ${ }^{125}$ I-insulin specifically bound as a function of increasing membrane protein concentration. Insulin binding increased linearly with lung membrane protein concentration. This represents data from several pools of fetal control membranes. Similar data was obtained for the other membranes studied.
All data are presented as the mean \pm 1 S.D. unless otherwise specified. Statistical comparisons were performed for all data utilizing the two-tailed Student $t$ test with significance determined at a level of $5 \%$ or less. For comparison of insulin binding to membrane pools, analysis of variance of the regression lines obtained for the binding curves was used.

\section{RESULTS}

Characteristics of maternal and fetal animals from control and alloxan-treated groups are shown in Table 1. Maternal glucose values were significantly greater in the alloxan-treated diabetic groups than in control $(246 \pm 81$ versus $98 \pm 7.0 ; P<0.001)$. Maternal insulin was undetectable in the alloxan-treated group. The lower limit of insulin detectable by the radioimmunoassay method was $4 \mu \mathrm{U} / \mathrm{ml}$. Fetal birth weights were lower in the diabetic offspring than the controls. Fetal glucose levels measured in the pooled serum were significantly greater in the offspring of the alloxan-treated mothers than in the control offspring (160 \pm 69 versus $55 \pm 12 \mathrm{mg} / \mathrm{dl} ; P<0.02$ ), reflecting a placental gradient of 1.2 for the diabetic animals and 1.6 for the normal animals. The mean insulin level of the diabetic offspring was more than double that of the control fetuses.

Crude membranes prepared from fetal and maternal lung tissue showed approximately two-fold enrichment of $5^{\prime}$-nucleotidase, a plasma membrane marker enzyme (Table 2). Binding of ${ }^{125} \mathrm{I}-$ insulin to membranes prepared from fetal and adult lung tissues was studied, and competitive binding curves from these studies are shown in Figure 2. Lung membranes from fetuses of alloxantreated diabetic mothers bound significantly more insulin than did lung membranes from control fetuses at tracer concentrations. Over the entire range of insulin concentrations at which insulin binding was studied, binding of insulin by fetal diabetic membranes was significantly higher than in normal controls $(P<$ $0.001)$. Although mean values of insulin binding by membranes from maternal controls were somewhat higher, they were not significantly different from binding by membranes from alloxandiabetic mothers.

Scatchard analyses of these competitive binding data are shown in Figure 3. Each point represents the mean value obtained at that insulin concentration for all experiments. The Scatchard plots are curvilinear for both maternal and fetal membranes. Figure $3 \mathrm{~A}$ depicts binding of insulin to membranes of the fetal animal groups, and Figure $3 B$ depicts binding to lung membranes from maternal control and alloxan-diabetic rabbits.

Analysis of these curvilinear Scatchard plots using a 2 receptor class model was carried out. The slope determined by linear regression analysis of the curve representing insulin bound at lower concentrations $(0.2$ to $10 \mathrm{ng} / \mathrm{ml})$ gives an estimate of the equilibrium affinity constant of a class of receptors of high affinity, and the intercept of the line of regression with the $\mathrm{x}$-axis gives an estimate of the binding capacity. Similar calculations were made to define the characteristics of the low-affinity receptors using data from insulin bound in the presence of insulin (10 to $100 \mathrm{ng} /$ $\mathrm{ml}$ ). The data derived from these calculations are shown in Table 3. High- and low affinity constants from maternal control lung membranes differ by one order of magnitude, and are comparable to those reported by Morishige et al. (18) for control adult rat lung. Maternal diabetic lung membranes have binding capacities of both high- and low-affinity receptors comparable with controls. Lower absolute values of affinity constants in both classes of receptors are observed in these diabetic preparations when compared to controls. Fetal control membranes have four- to five-fold greater numbers of affinity receptor as compared to maternal controls; in addition, they have five- to ten-fold more low-affinity receptors than maternal tissues.

Rates of ${ }^{125} \mathrm{I}$-insulin degradation by crude membrane preparations were compared for all four groups studied, and the data from these studies are shown in Figure 4. It is apparent that fetal membrane preparations from both control and diabetic offspring degrade significantly more ${ }^{125} \mathrm{I}$-insulin per $100 \mu \mathrm{g}$ membrane 
Table 1. Physical characteristics of maternal and fetal rabbits from control and alloxan-diabetic groups

\begin{tabular}{lccccc}
\hline & $\begin{array}{c}\text { Maternal glucose } \\
(\mathrm{mg} / \mathrm{dl})\end{array}$ & $\begin{array}{c}\text { Maternal insulin } \\
(\mu \mathrm{U} / \mathrm{ml})\end{array}$ & $\begin{array}{c}\text { Birthweight } \\
(\mathrm{g})\end{array}$ & $\begin{array}{c}\text { Fetal glucose } \\
(\mathrm{mg} / \mathrm{dl})\end{array}$ & $\begin{array}{c}\text { Fetal insulin } \\
(\mu \mathrm{U} / \mathrm{ml})\end{array}$ \\
\hline Group & & & & \\
Control & $98 \pm 7^{\prime}$ & $9 \pm 1$ & $34.7 \pm 1.1$ & $55 \pm 12$ & $23.2 \pm 3.7$ \\
Diabetic & $246 \pm 81^{2}$ & $<4$ & $31.2 \pm 0.8^{3}$ & $160 \pm 69^{3}$ & $84.8 \pm 24.9^{4}$ \\
\hline
\end{tabular}

'Mean \pm S.D.

${ }^{2} P<0.001$; control versus diabetic.

${ }^{3} P<0.05 ;$ control versus diabetic.

${ }^{4} P<0.02$; control versus diabetic.

Table 2. $5^{\prime}$-Nucleotidase content of lung homogenates and membranes ${ }^{1}$

\begin{tabular}{lccc}
\hline \multicolumn{1}{c}{ Group } & Homogenate & Membrane & $\begin{array}{c}\text { Fold- } \\
\text { enrichment }\end{array}$ \\
\hline Fetal control & $0.02 \pm 0.007^{2}$ & $0.038 \pm 0.006$ & 1.9 \\
Fetal diabetic & $0.02 \pm 0.006$ & $0.051 \pm 0.023$ & 2.5 \\
& & & \\
Maternal control & $0.069 \pm 0.006$ & $0.144 \pm 0.023$ & 2.0 \\
Maternal diabetic & $0.092 \pm 0.045$ & $0.186 \pm 0.079$ & 2.0 \\
\hline
\end{tabular}

${ }^{1}$ Data are expressed as $\mu$ mole of Pi generated per minute per $\mathrm{mg}$ protein.

${ }^{2}$ Mean \pm S.E.
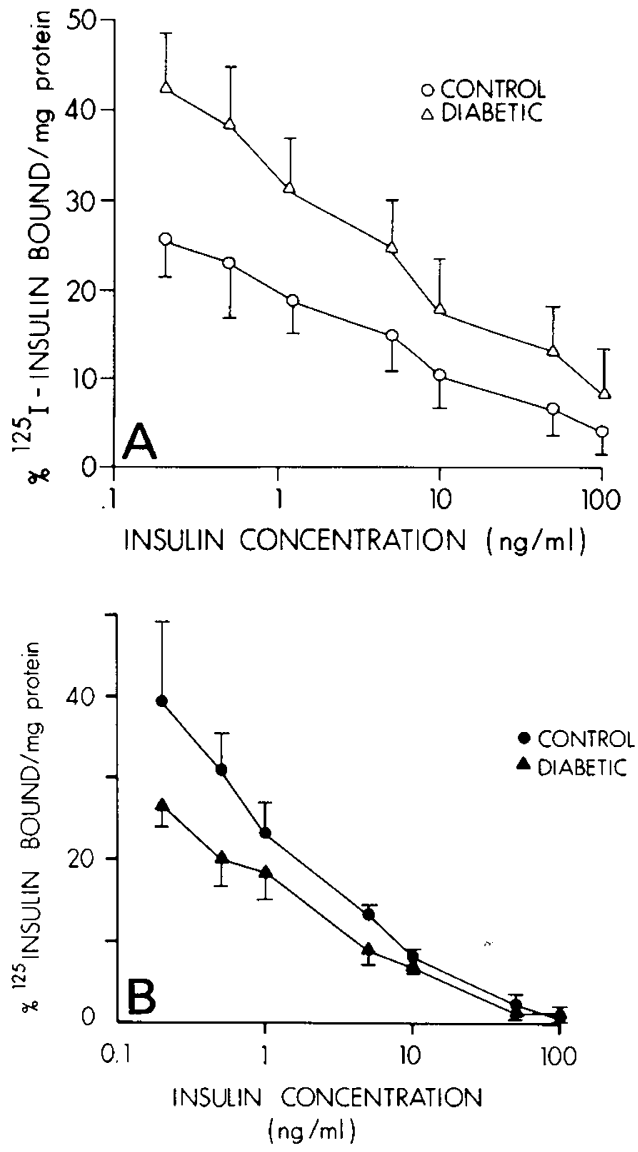

Fig. 2. A, competition curves of ${ }^{125} \mathrm{I}$-insulin binding to control $(O)$ and fetal diabetic $(\triangle)$ lung plasma membrane fractions. Data represent the mean \pm S.E. of duplicate determinations from eight pools of membranes. $(P<0.02$, and $P<0.05$ for fetal diabetic versus fetal control by analysis of paired differences); $B$, competition curves of ${ }^{125} \mathrm{I}$-insulin binding to maternal control $(\Theta)$ and maternal diabetic $(\boldsymbol{\Lambda})$ lung plasma membranes.

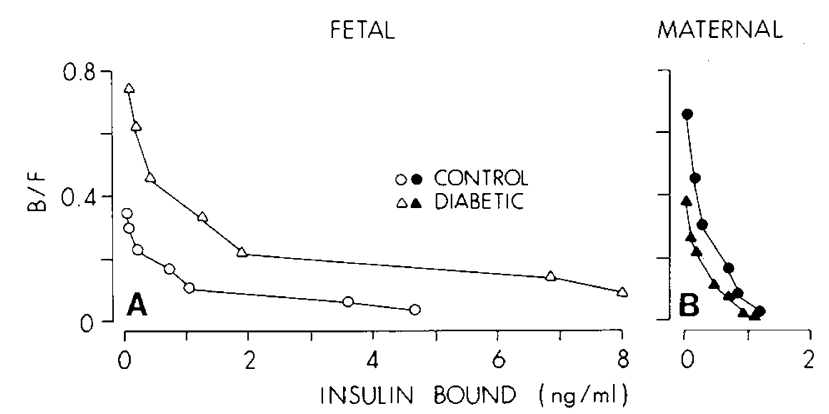

Fig. 3. Scatchard analysis of insulin binding to fetal control and diabetic lung plasma membrane fractions calculated from the competition curves shown (Fig. 1). Scatchard analysis of insulin binding to maternal lung plasma membranes.

Table 3. Affinity constants for a model of two receptor classes $^{1}$

\begin{tabular}{|c|c|c|c|c|}
\hline & \multicolumn{2}{|c|}{ Class 1} & \multicolumn{2}{|c|}{ Class 2} \\
\hline & $\mathrm{Ka}\left(\mathbf{M}^{-1}\right)$ & $\begin{array}{c}\text { Capacity } \\
\text { (moles/liter) }\end{array}$ & $\mathrm{Ka} \mathrm{M}^{-1}$ & $\begin{array}{c}\text { Capacity } \\
\text { (moles/liter) }\end{array}$ \\
\hline $\begin{array}{r}\text { Maternal } \\
\text { control }\end{array}$ & $1.3 \times 10^{10}$ & $5.1 \times 10^{-11}$ & $1.4 \times 10^{9}$ & $2.2 \times 10^{-10}$ \\
\hline $\begin{array}{l}\text { Maternal } \\
\text { diabetic }\end{array}$ & $6.7 \times 10^{9}$ & $4.7 \times 10^{-11}$ & $7.2 \times 10^{8}$ & $2.2 \times 10^{-10}$ \\
\hline $\begin{array}{l}\text { Fetal con- } \\
\text { trol }\end{array}$ & $1.5 \times 10^{9}$ & $1.5 \times 10^{-10}$ & $1.0 \times 10^{8}$ & $1.2 \times 10^{-9}$ \\
\hline $\begin{array}{l}\text { Fetal dia- } \\
\text { betic }\end{array}$ & $2.3 \times 10^{9}$ & $2.2 \times 10^{-10}$ & $1.5 \times 10^{8}$ & $2.1 \times 10^{-9}$ \\
\hline
\end{tabular}

' Class 1 (high-affinity receptors) are calculated by linear regression utilizing binding data obtained at points from 0.2 to $10 \mathrm{ng}$ insulin. The low-affinity, high-capacity receptors (class 2 ) are calculated from binding data obtained between points 10 to $100 \mathrm{ng}$ using the method of Blanchard et al. (5).

protein than do similarly prepared maternal membranes. Although fetal diabetic offspring have somewhat greater rates of insulin degradation than do control fetal membranes at 5- and 10min samples, the difference is not significant. At $30 \mathrm{~min}$, they are indistinguishable from one another. Insulin degradation rates by lung membranes from both control and diabetic mothers are similar.

\section{DISCUSSION}

Maternal treatment of rabbits or rats with a diabetogenic agent as a model for diabetes during pregnancy has been used by several groups in studies of fetal lung metabolism $(6,26,32)$. The rabbit model used by us resembles the human diabetic pregnancy in that maternal glucose concentrations are higher and insulin concentrations lower in the diabetic than in controls. Furthermore, in the offspring of the diabetic mother both glucose and insulin concen- 


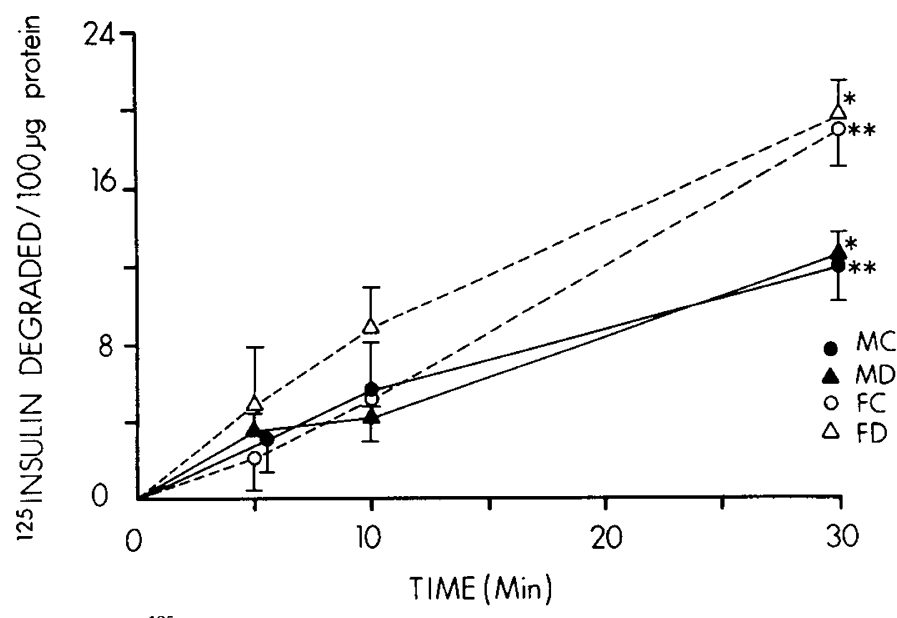

Fig. 4. ${ }^{125}$ I-Insulin degradation by fetal and maternal lung plasma membranes. Data represent the mean \pm S.E. of duplicate determinations of three separate experiments and are calculated as the percent of counts of total added radioactivity which appear in the trichloroacetic acid-soluble fraction, expressed per $100 \mu \mathrm{g}$ protein. $\left({ }^{* *}, P<0.025\right.$, maternal versus fetal control; * $P<0.005$ maternal versus fetal diabetics at $30 \mathrm{~min}$ ).

trations are higher than in controls. Failure of the fetuses of the diabetic mother to weigh more than the control fetuses has been observed by others when the fetuses are delivered prematurely $(11,16,34)$ as the case in these experiments. When gestation is prolonged beyond term in this model system, the offspring of the diabetic mothers do indeed weigh more than the offspring of controls (15).

Insulin receptors are present in fetal lung plasma membranes during the latter part of gestation at a time coincident with the onset of surfactant synthesis (10). The receptors have binding characteristics which are similar to those observed in other tissues $(5,13,22)$.

The effect of maternal diabetes during pregnancy on fetal insulin receptor development is of particular interest. Previous studies have shown that infants of diabetic mothers are hyperinsulinemic at birth and at the same time have significantly greater numbers of insulin receptors on circulating monocytes (19). Induction of maternal diabetes with alloxan resulted in significantly higher glucose levels in fetal blood and also much greater levels of fetal insulin as occurs in the human with diabetic pregnancy $(19,23,33)$. Despite the increase in fetal insulin levels, a reduction or down-regulation of insulin binding capacity was not observed. Thus, in agreement with previous observations on insulin receptors of monocytes in human cord blood, the fetus does not downregulate its lung receptors in the presence of hyperinsulinemia and is not able to protect itself from the adverse effects of insulin in vivo.

The insulin receptors studied here are derived from many lung cell types including type II cells, the cells primarily concerned with synthesis of surfactant (10). The conclusions drawn from studies of properties of mixed cell types, therefore, may not apply specifically to type II cells. On the other hand, it has been shown that other cells such as fibroblasts are involved in the regulation of surfactant production of type II cells (29). Studies such as this of receptor properties of multiple cell types may be of importance therefore, in gaining an understanding of the response of the lung as an organ responsible for surfactant production.

Several clinical investigations bear out the relationship between strict control of maternal blood glucose and fetal outcome during diabetic pregnancy, presumably by diminishing the degree of fetal hyperinsulinemia $(14,24,35)$. Included in the improvement in the clincal condition of the fetus is a significant reduction in the incidence of RDS. Strict diabetic control using insulin treatment during pregnancy results in a reduction of insulin receptor num- bers on cord blood monocytes to normal levels in IDM (20). The studies presented suggest a mechanism through which strict maternal control may work to alter insulin effects on fetal lung metabolism in diabetic pregnancies.

\section{REFERENCES AND NOTES}

1. Ames, B. N.: Assay of inorganic phosphate, total phosphate and phosphatases. Methods Enzymol., 8: 115 (1966).

2. Angervall, L.: Comparison between the action on the fetal pancreatic islets of alloxan injected to the pregnant rat to the fetuses in utero. Pathol. Microbiol., 26: 412 (1963).

3. Aronson, $\mathrm{N}$ N., and Touster, O.: Isolation of rat liver plasma membranes fragments in isotonic sucrose. Methods Enzymol., 31: 90 (1974).

4. Avery, M. E., and Mead, J.: Surface properties in relation to atelectasis and hyaline membrane disease. Am. J. Dis. Child., 97: 517 (1959).

5. Blanchard, R. F., Davis, P. J., and Blas, S. D.: Physical characteristics of insulin receptors on renal cell membranes. Diabetes, 27: 88 (1978).

6. Bose, C.L., Manne, D. N., D'Ercole, A. J., and Lawson, E. E.: Functional and biochemical alterations in lungs of fetuses of diabetic rabbits. Pediatr. Res., 14: 639 (1980).

7. deMeyts, P., Bianco, R., and Roth, J.: Site-site interactions among insulin receptors. J. Biol. Chem., 251: 1877 (1975)

8. Freychet, P., Roth, J., and Neville, D. M. Jr.: Insulin receptors in the liver; specific binding of ${ }^{125} \mathrm{I}$ insulin to the plasma membrane and its relation to insulin bioactivity. Proc. Natl. Acad. Sci. U. S. A., 68: 1833 (1971).

9. Gellis, S. S., and Hsia, D-Y. Y.: The infant of the diabetic mother. Am. J. Dis. Child., 97: 1 (1959).

10. Gilden, C., Sevanian, A., Tierney, D. F., Kaplan, S. A., and Barrett, C. T.: Regulation of fetal lung phosphatidylcholine synthesis by cortisol: role of glycogen and glucose. Pediatr. Res., 11: 845 (1977)

11. Golob, E. K., Risni, S., Becker, K. L., and Moore, C.: Streptozotcin diabetes in pregnant and non-pregnant rats. Metabolism, 19: 1014 (1970).

12. Gross, I., and Smith, G. J. W.: Insulin delays the morphologic maturation of fetal rat lung in vitro. Pediatr. Res. (Abstract), 11: 515 (1977).

13. Kahn, C. R., Freychet, P., Roth, J., and Neville, D. M., Jr.: Quantitative aspects of the insulin receptor interaction in liver plasma membranes. J. Biol. Chem., 249: 2249 (1974)

14. Karlssen, K., and Kjellmer, I.: The outcome of diabetic pregnancies in relation to the mother's blood sugar level. Am. J. Obstet. Gynecol., 112: 213 (1972).

15. Kim, J. N., Runge, W., Wells, L., and Lazarow, A.: Pancreatic islets and blood sugars in prenatal and postnatal offspring from diabetic rats: beta granulation and glycogen infiltration. Anat. Rec., 138: 239 (1960).

16. Lazarow, A., Kim, J. N., and Wells, L. J.: Birthweight and fetal mortality in pregnant subdiabetic rats. Diabetes, 9: 114 (1960).

17. Lowry, O. H., Rosebrough, N. J., Farr, A. L., and Randall, R. J.: Protein measurements with Folin phenol reagent. J. Biol. Chem., 193: 265 (1951).

18. Morishige, W. K., Uetake, C., Greenwood, F. C., and Akaka, J.: Pulmonary insulin responsivity: in vivo effects of insulin on the diabetic rat lung and specific insulin binding to lung receptors in normal rats. Endocrinology, 100: 1710 (1977).

19. Neufeld, N. D., Kaplan, S. A., and Lippe, B. M.: Increased monocyte receptor binding of $\mathrm{I}^{125}$ insulin in infants of gestational diabetic mother. J. Clin. Endocrinol. Metab., 47: 590 (1978).

20. Neufeld, N. D., Lippe, B. M., and Kaplan, S. A.: Normalization of insulin receptor binding in infants of diabetic mothers. Clin. Res., 27: 117A (1979).

21. Neufeld, N. D., Sevanian, A., Barrett, C. T., and Kaplan, S. A.: Inhibition of surfactant production by insulin in fetal rabbit lung slices. Pediatr. Res., 13: 752 (1979)

22. Olefsky, J. M., Johnson, J., Liu, F., Edwards, P., and Baurr, S.: Comparison of ${ }^{125} \mathrm{I}$ insulin binding and degradation to isolated rat hepatocytes and liver membranes. Diabetes, 24: 801 (1975).

23. Pederson, J.: The pregnant diabetic and her newborn. Problems and management. (Munksgaard, Copenhagen, 1967).

24. Persson, B., Gentz, J., and Kellum, M.: Metabolic observations in infants of strictly controlled diabetic mother. Acta Pediatr. Scand., 62: 465 (1973).

25. Pollet, R. J., Standaest, M. L., and Haase, B. A.: Insulin binding to the human lymphocyte receptor. Evaluation of the negative cooperativity model. J. Biol. Chem., 252: 5828 (1977).

26. Rhoades, R. A.: Influence of maternal diabetes on lipid metabolism in neonatal rat lung. Biochem. Biophys. Acta, 572: 132 (1979).

27. Robert, N. F., Neff, R. K., Hubbell, J. P. et al.: Association between maternal diabetes and the respiratory distress syndrome in the newborn. N. Engl. J. Med., 294: 357 (1976)

28. Scatchard, G.: The attraction of proteins for small molecules and ions. Ann. N. Y. Acad. Sci., 51: 660 (1949)

29. Smith, B.: Fibroblast pneumocyte factor intercellular mediator of glucocorticoid effect on fetal lung. In: L. Stern: Neonatal Intensive Care. pp. 25-32 (Masson, New York, 1978).

30. Smith, B. T., Girard, C. J. P., Robert, M., and Avery, M.: Insulin antagonism of cortisol action on lecithin synthesis by cultured fetal lung cells. J. Pediatr., 87: 953 (1975).

31. Soeldner, J. S., and Slone, D.: Critical variables in the radioimmunoassay of serum insulin using the double antibody technique. Diabetes, 14: 771 (1965).

32. Sosenko, I. R. S., Lawson, E. E., Demottaz, V., and Frantz, I. D.: Delayed lung 
maturation in fetuses of alloxan diabetic rabbits. Pediatr. Res., 12: 569 (1978).

33. Steinke, J., and Driscoll, S. G.: The extractable insulin content of pancreases from fetuses and infants of diabetic and control mothers. Diabetes, 14: 573 (1965).

34. van Assche, F. A.: The fetal endocrine pancreas. In: Carbohydrate Metabolism in Pregnancy and the Newborn. H. W. Sutherland. J. M. Stowers: p. 68, 115 , 151 (Churchill Livingston. London, 1975).

35. Whitelaw, A.: Subcutaneous fat in newborn infants of diabetic mothers: an indication of quality of diabetic control. Lancet, $1: 15$ (1977).
36. Dr. Neufeld is a recipient of a Clinical Investigator Award from the NIAMDD.

37. Requests for reprints should be addressed to: Naomi D. Neufeld, M. D. CedarsSinai Medical Center, Schuman Building Room 516, 8700 Beverly Boulevard, Los Angeles, CA 90048 (USA).

38. This research was supported by grants from the Kroc Foundation, Biomedical Research support Grant R R05468, NIH, and the Ariel Kaare Roscholt Weathers-Lowin Medical Research Foundation.

39. Received for publication August 19, 1980.

40. Accepted for publication November 17, 1980. 